Article

\title{
Routine or Rare Activity? A Quantitative Assessment of Parliamentary Scrutiny in the European Semester
}

\author{
Ivana Skazlic ${ }^{1,2}$ \\ ${ }^{1}$ Salzburg Centre for European Union Studies, University of Salzburg, Austria; E-Mail: ivana.skazlic@plus.ac.at \\ ${ }^{2}$ Research Group European Governance, Public Finance and Labor Markets, Institute for Advanced Studies, Austria
}

Submitted: 27 February 2021 | Accepted: 28 May 2021 | Published: 13 August 2021

\begin{abstract}
The European Semester is an EU procedure, designed to facilitate coordination between national and EU actors in planning and implementing economic and fiscal policies and contribute to sustained economic convergence and employment in the EU. Scholars have highlighted this procedure as a crucial area of EU politics for national parliaments since its introduction in 2011. However, national parliaments participate differently in the European Semester. This article investigates which factors (institutional, political, economic) are more likely to intensify parliamentary engagement at the national stage of the procedure, based on a comparative quantitative analysis of parliamentary scrutiny activities across 35 parliaments/chambers in the EU over the 2014-2017 period. The article offers new insights about prospects for greater parliamentary accountability in the European Semester in practice.
\end{abstract}

\section{Keywords}

European Semester; national parliaments; parliamentary accountability; parliamentary scrutiny

\section{Issue}

This article is part of the issue "Rising to a Challenge? Ten Years of Parliamentary Accountability of the European Semester" edited by Eric Miklin (University of Salzburg, Austria), Aleksandra Maatsch (University of Wroclaw, Poland) and Tomasz P. Woźniakowski (Hertie School, Germany).

(C) 2021 by the author; licensee Cogitatio (Lisbon, Portugal). This article is licensed under a Creative Commons Attribution 4.0 International License (CC BY).

\section{Introduction}

The European Semester (ES) is a policy coordination and monitoring procedure that follows national budgetary cycles at the EU level. The procedure enables greater EU level influence over a wide range of member states' policies with rules and requirements that can constrain national policy choices (Laffan, 2014; Laffan \& Schlosser, 2016). Most notably, it can affect decisions concerning national budgets, which is the most important prerogative of national parliaments. In this regard, scholars have highlighted this procedure as a crucial area of EU politics for national parliaments (de Wilde \& Raunio, 2018) and argued for a stronger parliamentary role and involvement in the ES to secure accountability and input legitimacy to the ES-related policy-making processes (Crum \& Merlo, 2020; Lord, 2017). Yet what national parliaments actually do in the procedure is still unclear. This contri- bution to the thematic issue investigates which institutional, political and economic factors are more likely to intensify parliamentary scrutiny of their government's programmes in the ES and thus contribute to domestic accountability.

The ES can create difficulties for parliamentary participation and challenge its abilities in monitoring the government's EU-level actions and obligations concerning fiscal and economic policies in several aspects. This relates to the ES 'hybrid' mode of governance (Armstrong, 2013; Dawson, 2015) that diverts from standard EU decision-making and legislative procedures, the fact that there are no specific EU provisions for the formal involvement of national parliaments (Amtenbrink \& Repasi, 2016), and the functioning of the procedure as an ongoing cycle with intensive exchanges between the European and national authorities in yearly revisions of national policy plans and EU recommendations 
(Crum \& Curtin, 2015; Dawson, 2015). As a result, the ES does not only add another layer of complexity to EU-level policy-making but it also requires significant efforts from national parliaments to effectively follow the procedure and respond to its constraining aspects over national policy choices that might stretch their capacities and motivation.

Empirical studies so far have pointed to uneven participation of national parliaments and highlighted the importance of both formal powers and motivation in influencing parliamentary decisions to scrutinise the ES. Rasmussen (2018) stressed the importance of formal powers and monitoring capabilities for effective parliamentary involvement in the ES. Still, Kreilinger (2018) argued that active parliamentary ES scrutiny depends on domestic political dynamics and economic strength, while formal powers are a precondition for greater scrutiny. The study by van den Brink (2018) pointed out that parliaments are rather selective when considering more active ES scrutiny, depending on the perceptions of the policy impact this might have in the procedure. Maatsch (2017) showed that contestation of the ES is more likely to occur when parliament has strong budgetary powers and there is incongruence between EU recommendations and parliamentary party economic preferences. Overall, the empirical evidence is scarce and because the existing assessments focused on parliamentary participation in different ES cycles and examined the impact of different factors at different stages of the procedure, findings are not always directly comparable and a general overview is still lacking.

Against this background, this article contributes with a comparative analysis of the ES scrutiny activities across 35 parliamentary chambers in the EU over the 2014-2017 period. The analysis does not include the Greek parliament (Greece did not fully participate in the ES during the observed period), and parliaments from Malta and Cyprus (lack of data for operationalisation of variables for the analysis). In addition, the upper chambers in Austria and Belgium (no formal competencies) and Slovenia (specific composition complicates operationalisation of variables for the analyses) are not included.

The contribution of the article is threefold. First, methodologically, it provides an operationalisation of the parliamentary scrutiny in the ES that allows for a distinction between passive/minimal and active/greater participation in the procedure. Second, empirically, it offers a comparative analysis of parliamentary ES scrutiny activities and makes it possible to test the explanatory power of factors commonly argued in the literature to be influencing parliamentary participation in EU policy-making on a larger number of observations and over a longer period. The aim is to provide a general overview of parliamentary engagement in ES scrutiny in practice and thus contribute to still scarce empirical research on parliamentary behaviour in the EU economic governance. Finally, the article con- tributes to the broader debate about the parliamentary accountability and democratic legitimacy of the EU economic governance.

The remainder of this article is structured as follows. Section 2 discusses how the parliamentary scrutiny in the ES can be operationalised quantitatively and also includes elements for greater accountability. Drawing on previous research, the third section outlines theoretical expectations. Data and operationalisation are presented in the fourth section, followed by the empirical analysis in the fifth section. The final section concludes.

\section{Measuring Parliamentary Scrutiny of the S/CP-NRP}

This article focuses on parliamentary engagement at the national stage of the ES when national governments are required to report on their plans for achieving defined budgetary objectives (Stability or Convergence Programme [S/CP]) and actions related to broader socioeconomic policies (National Reform Programme [NRP]) and how they will contribute to achieving EU priorities and targets. These programmes have to be submitted to the Commission for review by the end of April each year. Based on the assessment of the S/CP-NRP, the Commission prepares policy recommendations that are expected to be implemented by the member states. An adequate parliamentary involvement in the preparation process of the S/CP-NRP is necessary to ensure that government's planned policy actions, and its EU commitments and their implications, are properly assessed, discussed and justified, i.e., that the government is accountable for its ES decisions.

In the context of this thematic issue, accountability is defined as a chain of exchanges between accountor (here the members of parliament) and accountee (here members of government), whereby the former asks questions about policies and actions of the latter, while the latter must provide answers (Wozniakowski et al., 2021). To be able to systematically assess parliamentary accountability mechanisms at the national stage of the ES across different parliaments in practice, this study relies on the existing literature measuring parliamentary scrutiny in EU affairs for selection of elements and indicators (Auel et al., 2015a; Karlas, 2011; Maurer \& Wessels, 2001; Raunio, 2005; Winzen, 2012; for an overview see also Auel \& Neuhold, 2018). These are adjusted to the ES context and used to develop scrutiny activity scores (see Table 1). I will briefly discuss selected elements and how they contribute to enhancing parliamentary scrutiny and control over the government in the ES.

The number of committee meetings and/or plenary debates can already indicate the intensity of scrutiny of the S/CP-NRP and allows for an initial distinction between passive and active parliamentary engagement (the first element). Since all ES-related documents are eventually available online, including the S/CP-NRP, it is important that parliaments obtain 
Table 1. Indicators measuring parliamentary scrutiny of the S/CP-NRP.

\begin{tabular}{ll}
\hline Elements & Measurement \\
\hline Intensity & $\begin{array}{l}\text { Number of committee meetings } \\
\text { Number of plenaries }\end{array}$ \\
Access to additional information & $\begin{array}{l}\text { Number of hearings with: } \\
\text { - Representatives from the Government } \\
\text { - EU officials } \\
\text { - Experts/Stakeholders }\end{array}$ \\
Outcome & $\begin{array}{l}\text { Number of parliamentary statements on the programmes } \\
\text { Number of parliamentary votes on the programmes }\end{array}$ \\
Mainstreaming the ES & $\begin{array}{l}\text { Number of committees involved in the scrutiny } \\
\text { Plenary debate, counted as a maximum number of committees involved }\end{array}$ \\
& $\begin{array}{l}\text { Number of days passed since the first scrutiny activity took place before the S/CP-NRP } \\
\text { were sent to the Commission (April 30) }\end{array}$ \\
\hline
\end{tabular}

Note: Suggested indicators and measurements are based on the literature cited directly above.

additional information on these programmes and their implications. This can be done via parliamentary hearings (the second element). In particular, hearings with the government allow for a targeted discussion about the government's planned activities and additional explanations, while hearings with EU representatives and relevant experts can provide a source of independent information and additional expert assessments. This can help parliaments to examine government plans more effectively, and ensure greater accountability. The third element relates to parliamentary resolutions or voting on the S/CP-NRP (all contributions on which I rely for selection of elements emphasise and include this aspect for EU affairs more generally).

Parliaments that employ these instruments can better articulate their position concerning the government's plans and EU level commitments in the S/CP-NRP and highlight potential disagreements and their preferred course of action. This, in turn, can increase the government's anticipation of parliamentary reaction and incentivise greater discussions to provide pertinent explanations, thus ensuring greater accountability (here, see also Rozenberg, 2017). Furthermore, since the ES is an intensive and technical procedure that covers extensive policy areas, the way parliaments process ES issues, i.e., the mainstreaming is important (the fourth element). For example, the literature emphasises the benefits of relying on sectoral expertise in ensuring effective scrutiny (here, see also Gattermann et al., 2016). Sectoral committees can provide specialised assessments of different policy areas covered in the S/CP-NRP and contribute to expert discussion and efficient scrutiny performance. Scrutiny of these programmes in plenary can ensure broader political discussion on relevant ES issues and their implications. Both aspects can enhance parliamentary accountability. Finally, the timing of parliamentary involvement (the fifth element) is important because effective scrutiny requires sufficient time for the review of the S/CP-NRP. Since the ES operates according to specified deadlines, it is relevant to consider not just when parliaments receive relevant documents but also when the scrutiny process actually starts.

\section{Explaining the Variation}

To explain the variation in the S/CP-NRP scrutiny across parliaments/chambers, I test the explanatory power of three sets of factors that have been found in the literature to play a role in observed differences of parliamentary participation in EU policy-making. These include the national institutional context $(\mathrm{H} 1 \mathrm{a}, \mathrm{H} 1 \mathrm{~b})$ and political $(\mathrm{H} 2, \mathrm{H} 3 \mathrm{a}, \mathrm{H} 3 \mathrm{~b})$ and economic (H4) incentives.

The literature highlighted the importance of the institutional context for the overall parliamentary activity since it determines formal rules and provides institutional opportunities (Auel et al., 2015b; Raunio, 2011). Because the ES is an EU level exercise that is particularly focused on national public finances, parliamentary strength in both EU and budgetary matters is important for engagement of national parliaments in this exercise and parliamentary ability to effectively scrutinise the S/CP-NRP and (if necessary) constrain government actions as well as EU level commitments. Powerful parliaments in EU and budgetary matters can obtain relevant information more easily and are in a better position to secure timely and substantial scrutiny of the S/CP-NRP.

$\mathrm{H} 1 \mathrm{a}$ : The greater the parliamentary strength in EU affairs, the greater S/CP-NRP scrutiny

$\mathrm{H} 1 \mathrm{~b}$ : The greater the parliamentary strength in budgetary matters, the greater S/CP-NRP scrutiny

However, a strong parliamentary position and formal opportunities to hold the government accountable do not necessarily translate into de facto activity (Auel 
et al., 2015a). The extent to which parliaments make use of available formal means to monitor the government will vary depending on executive-legislative relations (Raunio, 2011). Moving beyond a view of parliament as a collective actor, different parliamentary actors will have different interests when it comes to more intensive scrutiny of the government's policies and actions, and they are expected to employ different strategies (Auel, 2007; Raunio, 2011). The interest of the parliamentary opposition is to criticise the government's planned or implemented policies and/or propose alternative solutions (Karlsson \& Peterson, 2018), so it will be more likely to demand greater political accountability from the government (Auel, 2007) in the ES (Kreilinger, 2018). By contrast, the governing parliamentary majority is expected to be less motivated to thoroughly scrutinise the government's ES agenda (Kreilinger, 2018) and more prone to support the government in respecting EU commitments and agreements (Rose, 2014). Therefore, the greater the seat share the governing parties hold in the parliament and the greater the margin over the opposition, the more the government can rely on its parliamentary support to push forward its ES agenda.

$\mathrm{H} 2$ : The greater the seat share of the governing parties in parliament, the lower S/CP-NRP scrutiny

Divergent intra-parliamentary political stances on respective policy areas and issues can also incentivise greater scrutiny (Gattermann \& Hefftler, 2015). The ES enables enhanced EU surveillance of key national policies whereby the Commission assesses national fiscal and economic plans and can recommend financial sanctions. Such strong EU-level presence in national matters coupled with the enhanced EU rules and monitoring mechanisms can especially incentivise Eurosceptic parliamentary parties to challenge the ES agenda for their electoral and policy advantages. Particularly so since formerly depoliticised issues related to EU economic governance have become increasingly salient (Leupold, 2016). Based on previous research (Gattermann \& Hefftler, 2015; Raunio, 2005), such potential of political contestation of the EU in parliament is expected to positively correlate with tighter scrutiny.

$\mathrm{H} 3 \mathrm{a}$ : The higher the conflict potential over the EU in parliament, the greater S/CP-NRP scrutiny

The ES touches upon politically salient issues of national economic and social development. For quite some time, the ES was oriented more towards fiscal consolidation (Falkner, 2016; Zeitlin, 2016). In terms of general economic policy preferences, this approach is more likely to be supported by economically right-leaning parties, with economically right-wing governments being better placed to implement such policies (Alesina et al., 1997; Eihmanis, 2018). By contrast, since economically leftleaning parties generally prefer more generous social policies (Alesina et al., 1997), there might be a wider gap between the ES policy approach and the preferences of these parties. Additionally, EU fiscal rules might be especially constraining for the preferred policy choices of the parties representing the economic left. Since the parliamentary politicisation of EU economic governance evolved around national economic interests (Maatsch, 2017; Wonka, 2016), a greater potential for disagreement along ideological left-right economic lines in parliament is expected to incentivise scrutiny of the S/CP-NRP to secure preferred policy outcomes.

$\mathrm{H} 3 \mathrm{~b}$ : The higher the conflict potential on the economic issues in parliament, the greater S/CP-NRP scrutiny

Finally, previous research showed that the national economic situation has had a positive impact on parliamentary scrutiny during the Eurozone crisis (Auel \& Höing, 2015), and even in the period after the crisis (Kreilinger, 2018). Since member states across the EU strive to maintain a positive economic outlook and restore and/or secure their credibility on the financial markets and the confidence of foreign investors, unfavourable economic situations and their potential economic and political consequences are expected to attract parliamentary attention. Importantly, problematic budgetary and macroeconomic developments detected within the ES can lead to the opening of procedures for excessive deficits and/or macroeconomic imbalances, accompanied by stricter EU surveillance, which is expected to incentivise greater parliamentary scrutiny of the government's plans and actions in the ES.

$\mathrm{H} 4$ : The more unfavourable the national economic situation, the greater S/CP-NRP scrutiny

\section{Data and Operationalisation}

\subsection{Dependent Variable}

The dependent variable is a score for the parliamentary scrutiny activities related to the S/CP-NRP, calculated for each parliament/chamber and each year under the investigation (see Figure 1). The score is based on five elements and consists of ten indicators that were presented and discussed in section two of this article. Data on the S/CP-NRP scrutiny activities was collected in an original quantitative dataset, using various sources (the ES documents, parliamentary websites and the IPEX database). Additional data and materials were directly obtained from parliamentary officials, which also verified all collected data for their respective parliament/chamber (with few exceptions, including the Belgian, the Bulgarian and the Swedish parliament as well as the Romanian Senate and the Slovenian National Assembly). The dataset includes a total of 309 parliamentary scrutiny activities. The final sample consists of 


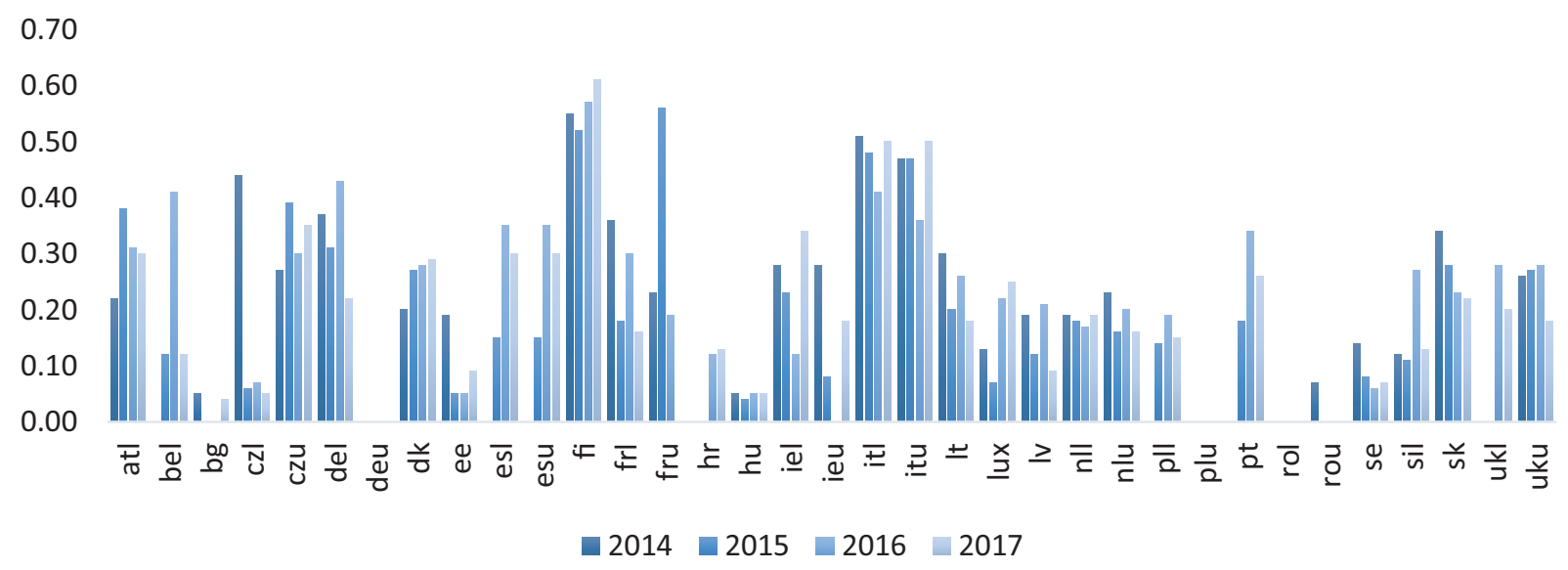

Figure 1. Parliamentary S/CP-NRP scrutiny scores. Notes: The figure shows overall scrutiny activity in a specific year in comparison to the most engaged parliaments/chambers; Portugal did not fully participate in the ES in 2014; ' $L$ ' stands for lower and ' $U$ ' for upper chamber for bicameral parliaments.

140 chamber-year observations. A detailed overview of yearly scores and explanations of employed methods of aggregation and weighting is provided in Table A1 in the Supplementary File.

\subsection{Independent Variables}

Table 2 presents the main independent variables that test the formulated hypotheses. All variables are measured at the chamber level, with exception of the economic situation, Eurozone membership and public Euroscepticism, which are measured at the country level. Variables measuring the seat share of governing parties in parliament, and the conflict potential over EU and economic issues in parliament are re-calculated after each parliamentary election to account for the changes. The variable measuring public Euroscepticism and the economic situation is calculated yearly. Table $A 2$ in the Supplementary File provides summary statistics for all variables used in the analyses.

\section{Empirical Analysis}

To account for the multilevel hierarchical structure and the longitudinal aspect of the data, I employ multi-level modelling. The data on scrutiny activities of 35 parliaments/chambers (level-1) is nested within 25 countries (level-2). Statistical evidence obtained by the inter-class correlation coefficient (ICC) demonstrated hierarchical structure effects on the outcome variable: 53 percent of the total variation is due to differences between countries. The follow-up likelihood ratio tests confirmed that the multi-level model is preferred over a classical, singlelevel model. Temporal effects were not confirmed by the performed initial tests, and are, therefore, not included in further analyses and model specifications.

I conducted a series of fixed slope, random intercept multi-level analyses. Model 1 predicts the outcome using institutional factors only. Model 2 introduces the polit- ical, while Model 3 adds the economic factors. Finally, Model 4 is a full model that includes all three sets of factors and control variables. Predictor variables in the analysis are not centred, considering the small sample size and limited year intervals as well as the fact that there is no collinearity issue detected.

Table 3 presents the estimation results of the multilevel analyses for the parliamentary scrutiny of the S/CP-NRP as the outcome variable (for all robustness tests see the Supplementary File). Different model specifications yielded similar results. The results confirm the effect of the formal powers in EU affairs at the 99 percent level. The effect is also considerable: Increasing the OPAL score (range: $0.21-0.84$ ) by 0.1 results in an increase of 0.06 in the S/CP-NRP scrutiny score (range: 0-0.61), which amounts to a yearly scrutiny score of some parliaments. The effect of the debt level is also confirmed with a statistical significance at the 99 percent level: Higher government debt-to-GDP level is associated with higher scrutiny of the S/CP-NRP. For every unit increase in the government debt level, a 0.002 unit increase in the S/CP-NRP scrutiny score is predicted. Considering that the levels of government debt range from 9.5 to 132.6, this effect is not as small as the small coefficient in the analysis suggests. Furthermore, the results indicate a negative effect of the greater seat share of the governing parties in the parliament on the scrutiny of S/CP-NRP, as expected. Yet this finding is not robust under different model specifications and cannot be reported with confidence.

By contrast, the effect of the budget amendment powers ( $\mathrm{H} 1 \mathrm{~b})$ is not confirmed: The association with the outcome variable does not have the expected direction and does not conform to conventional levels of significance. The conflict potential over the EU (H3a), as well as economic issues $(\mathrm{H} 3 \mathrm{~b})$, do not have statistically observable effects either. Finally, the effects of control variables point in the expected direction but are not statistically confirmed. The limited variation in 
Table 2. Independent variables and operationalisation.

\begin{tabular}{lll}
\hline Independent variable & Operationalisation & Source \\
\hline EU affairs powers (H1a) & The OPAL score measuring the institutional parliamentary strength & Auel et al. (2015a) \\
& in EU affairs, updated to include Croatia. &
\end{tabular}

Budget powers (H1b)
Measured as legally prescribed arrangements for a parliament to amend the budget with the following categories: $0=$ no amendments allowed; 0.5 = amendments allowed with certain limitations; 1 = unconstrained amendments.

$\operatorname{OECD}$ (n.d.)

The seat share of governing parties in the parliament (H2)

Conflict potential: EU (H3a)

Conflict potential: economic issues (H3b)

Economic situation (H4)

Elections (control variable)

Eurozone membership (control variable)

Public Euroscepticism (control variable)
The 'total government support' variable in the CPDS dataset measuring parliamentary seat share of all parties in the government, weighted by the numbers of days in office in any given year. The variable allows accounting for all changes in the size of governing parliamentary parties in any given year under examination.

Calculated based on the formula for the weighted parliamentary party system dispersion provided by Gattermann and Hefftler (2015, p. 134), using data on party positions on the European integration from the 2014 and 2017 rounds of the CHES expert survey.

Calculated based on the formula for the weighted parliamentary party system dispersion provided by Gattermann and Hefftler (2015, p. 134), using data on party ideological stances on economic issues from the 2014 and 2017 rounds of the CHES expert survey.

Measured as the gross general government debt as a percentage of GDP.

Binary variable with value 1 when parliamentary elections took place two months before the 30 April deadline for the submission of national programmes. The organisation of the parliamentary elections close to this deadline is expected to negatively affect scrutiny activity due to campaigning, and the dissolution of the parliament due to elections.

Binary variable with value 1 for formal membership in the Eurozone. The expectation is that the Eurozone parliaments will have more incentives for greater scrutiny since there are more EU requirements and also the possibility of sanctions within the ES for the Eurozone member states.

Measured as the percentage of citizens per year stating that their country did not benefit from EU membership, relying on the European Parliament 2014-2017 Parlemeter surveys as a data source. The expectation is that parliamentarians in more Eurosceptic member states will have more incentives to actively participate in the ES for their electoral purposes.
Polk et al. (2017)

Polk et al. (2017)

Armingeon et al. (2019)

Polk et al. (2017)

Polk et al. (2017)

Eurostat (2021)

Armingeon et al.

European

Parliament (n.d.) data could be the reason for the statistically insignificant negative effect of parliamentary elections since only 6 chambers had elections shortly before the 30 April deadline. Eurozone membership shows a positive effect on scrutiny but it is not statistically significant, suggesting that the S/CP-NRP scrutiny is not more important for Eurozone parliaments (see also Auel \& Höing, 2015). Still, additional tests which model some individual dimensions of the overall S/CP-NRP scrutiny score separately, suggest that Eurozone parliaments are more likely to rely on the specialised expertise within the parliament by including more sectoral committees in the scrutiny process (see Table A5 in the Supplementary File). Finally, the effect of public Euroscepticism on parliamentary scrutiny 
Table 3. Multilevel models for the parliamentary scrutiny of the S/CP-NRP.

\begin{tabular}{|c|c|c|c|c|}
\hline DV: Scrutiny score SCP/NRP & Model 1 & Model 2 & Model 3 & Model 4 \\
\hline EU affairs powers & $\begin{array}{l}0.528 * * * \\
(0.149)\end{array}$ & $\begin{array}{l}0.569 * * * \\
(0.157)\end{array}$ & $\begin{array}{l}0.660 * * * \\
(0.136)\end{array}$ & $\begin{array}{l}0.613 * * * \\
(0.133)\end{array}$ \\
\hline Budget amendment powers & $\begin{array}{l}-0.0395 \\
(0.0464)\end{array}$ & $\begin{array}{c}-0.0470 \\
(0.0469)\end{array}$ & $\begin{array}{c}-0.0621 \\
(0.0428)\end{array}$ & $\begin{array}{l}-0.0543 \\
(0.0426)\end{array}$ \\
\hline Seat share govt parties & & $\begin{array}{l}-0.00232 \\
(0.00137)\end{array}$ & $\begin{array}{c}-0.00281^{*} \\
(0.00130)\end{array}$ & $\begin{array}{c}-0.00283^{*} \\
(0.00130)\end{array}$ \\
\hline EU conflict & & $\begin{array}{l}-0.00227 \\
(0.00374)\end{array}$ & $\begin{array}{l}-0.000991 \\
(0.00339)\end{array}$ & $\begin{array}{l}0.0000152 \\
(0.00338)\end{array}$ \\
\hline Economic conflict & & $\begin{array}{c}0.00214 \\
(0.00318)\end{array}$ & $\begin{array}{c}0.00173 \\
(0.00285)\end{array}$ & $\begin{array}{r}0.000900 \\
(0.00290)\end{array}$ \\
\hline Govt debt to GDP & & & $\begin{array}{l}0.00253^{* * *} \\
(0.000611)\end{array}$ & $\begin{array}{c}0.00236 * * * \\
(0.000676)\end{array}$ \\
\hline Elections $=1$ & & & & $\begin{array}{c}-0.0118 \\
(0.0463)\end{array}$ \\
\hline Eurozone membership=1 & & & & $\begin{array}{c}0.0461 \\
(0.0400)\end{array}$ \\
\hline No benefits & & & & $\begin{array}{l}-0.000395 \\
(0.00154)\end{array}$ \\
\hline Constant & $\begin{array}{l}-0.0595 \\
(0.0770)\end{array}$ & $\begin{array}{c}0.0374 \\
(0.133)\end{array}$ & $\begin{array}{l}-0.152 \\
(0.127)\end{array}$ & $\begin{array}{c}-0.137 \\
(0.126)\end{array}$ \\
\hline \multicolumn{5}{|l|}{ Ins1_1_1 } \\
\hline Constant & $\begin{array}{l}-2.241 * * * \\
(0.177)\end{array}$ & $\begin{array}{l}-2.207^{* * *} \\
(0.184)\end{array}$ & $\begin{array}{l}-2.482 * * * \\
(0.213)\end{array}$ & $\begin{array}{l}-2.549 * * * \\
(0.237)\end{array}$ \\
\hline \multicolumn{5}{|l|}{ Insig_e } \\
\hline Constant & $\begin{array}{l}-2.277^{* * *} \\
(0.0667)\end{array}$ & $\begin{array}{l}-2.299 * * * \\
(0.0676)\end{array}$ & $\begin{array}{l}-2.312 * * * \\
(0.0684)\end{array}$ & $\begin{array}{l}-2.307^{* * *} \\
(0.0698)\end{array}$ \\
\hline Observations & 140 & 140 & 140 & 140 \\
\hline
\end{tabular}

Notes: ${ }^{*} p<0.05 ;{ }^{*} p<0.01 ; * * * p<0.001 ;$ standard errors in parentheses.

points in a negative direction but it is not statistically confirmed, suggesting that more sceptical public opinion towards the EU does not necessarily create incentives for parliamentarians to actively engage in the ES. There are, however, some indications that more sceptical public opinion towards the EU might hurt the timing of parliamentary scrutiny, disincentivising an earlier start of scrutiny activities related to the S/CP-NRP (see Table A5 in the Supplementary File).

To summarise, the statistical evidence selectively confirms the importance of institutional factors in explaining parliamentary S/CP-NRP scrutiny. All variants of the model provide empirical support for the expectation that formal strength in EU affairs is an important predictor for greater scrutiny $(\mathrm{H} 1 \mathrm{a})$. The scores show, for example, active engagement of the Finnish parliament, the Czech upper chamber and the German lower chamber in the S/CP-NRP scrutiny, which are considered among the most powerful parliaments in EU affairs (see Auel et al., 2015a). The Swedish and
Estonian parliaments are some noticeable exceptions in this regard. Surprisingly, and contrary to the expectation ( $\mathrm{H} 1 \mathrm{~b})$, the budget-amending powers do not seem to increase the likelihood of greater scrutiny. One possible interpretation could be that parliaments with strong budgetary powers already have institutional opportunities to actively engage and influence the government's public finance policies and scrutinise EU-related fiscal obligations within the national budgetary process, and therefore, invest fewer efforts in the S/CP-NRP scrutiny. In other words, parliaments with a stronger budgetary position may not have to rely on the ES scrutiny to effectively hold their government to account and monitor the implementation of budgetary policies, including compliance with EU requirements. The S/CP-NRP then may not warrant intensive scrutiny. The Finnish parliament is an outlier because it enjoys unconstrained budget amendment powers (Wehner, 2006) but also intensively scrutinised national ES programmes. This is because the ES is well aligned with the existing budgetary timeline in 
Finland (Leino-Sandberg \& Salminen, 2014). The Stability Programme is part of the government's Public Finance Programme and is scrutinised following a regular budgetary process.

Another surprising finding is that there is no strong statistical evidence of the effect of political-motivational incentives on the S/CP-NRP scrutiny ( $\mathrm{H} 2, \mathrm{H} 3 \mathrm{a}, \mathrm{H} 3 \mathrm{~b})$. All tested factors seem to be either unstable or negligible predictors for greater scrutiny. There is some evidence that the greater parliamentary seat share of the governing parties decreases scrutiny activity, but the effect is unstable. The observation that fundamental lines of political conflict in parliament are not what is driving greater scrutiny of the S/CP-NRP could correspond to findings by Rasmussen (2018) and van den Brink (2018), who showed that in some parliaments there is a lack of political motivation to perform greater scrutiny when these programmes provide a summary of policies that have been discussed and agreed upon within national processes. Also, some of these programmes refer to EU priorities/targets rather generally and do not always specify how the outlined measures will address them (European Court of Auditors, 2020). Increased party-political contestation might, however, occasionally spur scrutiny in some specific instances in some cases (Kreilinger, 2018; Maatsch, 2017). Further qualitative research is needed to uncover whether and how exactly party-political factors impact the S/CP-NRP scrutiny and whether pro/anti-EU and economic left/right lines of conflict become visible in parliamentary discussions of these programmes although they might not need to necessarily invoke them.

Finally, the statistical evidence confirms the importance of the economic incentives $(\mathrm{H} 4)$ but requires further specification. The results suggest that with the increase of government debt, parliamentary attempts to secure their participation in the ES seem to be greater, and scrutiny of the S/CP-NRP tends to be more active. The scores show that parliaments whose countries had high debt levels, such as the French, the Italian and the Portuguese parliaments, for example, performed greater scrutiny. Importantly, other economic indicators that are commonly used to assess the national economic situation, such as the unemployment rate or national credit ratings do not seem to affect the parliamentary S/CP-NRP scrutiny (for the results of all tested economic indicators see Tables $A 3$ and $A 4$ in the Supplementary File). One possible interpretation could be that in the ES, national parliaments tend to focus on the debt level as the core economic indicator, considering that its limits are defined by the Maastricht Treaty and closely monitored at the EU level within the procedure. Excessive debt levels can trigger stricter EU surveillance over national policies within the ES, increasing the pressure on national governments to take corrective actions effectively. For Eurozone members, there is also a threat of sanctions in case of consistent non-compliance. Other economic indicators are relevant for overall economic performance. Yet, possibly because these indicators do not carry as serious implications for the member state governments within the ES as the high public debt level, they do not incentivise greater parliamentary scrutiny.

\section{Conclusion}

The ES procedure is a central part of the EU economic governance, aimed at contributing to the financial and economic stability and sustainability of the Eurozone/EU. Yet whether it has weakened the role and abilities of national parliaments to scrutinise/control fiscal and economic policies is still being questioned (Wozniakowski et al., 2021). This article assessed the participation of national parliaments in the ES in practice, investigating which factors help to explain the variation in parliamentary scrutiny of the S/CP-NRP. The developed scrutiny activity scores allowed for an assessment from a broad comparative perspective and during four ES cycles.

Before concluding, two caveats are in order. The first is related to the effect of budgetary powers on the parliamentary scrutiny activity. I accounted for this aspect in a limited way since I only considered budget amendment powers, which usually highly correlate with the overall budgetary strength (Wehner, 2006) and are an important factor in explaining cross-parliamentary variation in the budgetary procedure (Wehner, 2014). More comprehensive indicators exist (Hallerberg et al., 2012; Wehner, 2006) but they include only lower chambers and/or do not include all EU member states, and hence, were not suitable for the analysis. There is a need for an indicator of the parliamentary budgetary strength that would cover all parliamentary chambers in the EU. Including such an indicator in the analysis would provide firmer results on the effect of parliamentary budgetary powers on the S/CP-NRP scrutiny. I found a negative yet insignificant effect of these powers on the S/CP-NRP scrutiny activity but this does not mean that they are not important for the parliamentary following of the procedure overall and especially parliamentary abilities to effectively process ES-related budgetary and macroeconomic requirements.

The second is related to some limitations of the developed scrutiny activity scores that have to be mentioned. The scores reveal only a specific portion of parliamentary ES activities. They concern the S/CP-NRP exclusively and do not consider other ES documents/stages. Also, the scores do not include all possible parliamentary scrutiny activities (for example oral questions). Moreover, while the scores measure different degrees of parliamentary scrutiny, they cannot capture actual parliamentary impact. The parliamentary participation in the ES involves complex political considerations and interactions on both national and EU levels, which cannot be easily detected or quantified. A more qualitative approach would be required to assess how successfully parliaments managed to exert their influence in the ES. 
Despite these limitations, the findings show that the majority of national parliaments/chambers scrutinised the S/CP-NRP, although with considerable variation concerning their activities. Few parliaments/chambers did not engage in scrutiny of the S/CP-NRP at all, while some parliaments performed scrutiny only irregularly. In explaining cross-parliamentary variation, the empirical evidence indicates two important predictors for greater scrutiny of the S/CP-NRP: formal strength in EU affairs and government debt level, as a specific economic incentive.

Formal powers and capacities in EU affairs can facilitate engagement in the ES as an EU level procedure, and national parliaments tend to use their available institutional opportunities to scrutinise S/CP-NRP more actively. Previous research on parliamentary behaviour in the ES/EU affairs argued that formal powers in EU affairs are an important prerequisite for greater scrutiny activity (Auel \& Höing, 2015; Auel et al., 2015b; Kreilinger, 2018; Rasmussen, 2018). In this regard, the lack of adequate institutional opportunities can constrain effective parliamentary scrutiny of the government's planned actions concerning EU requirements and targets outlined in national ES programmes in practice. This highlights the importance of parliamentary institutional adaptation in the ES (see Winzen, 2021).

Moreover, it seems that financial stability, which is central to the ES policy coordination and monitoring, captures parliamentary attention. When public finance liability (approximated with the public debt) is at risk, national parliaments tend to increase their attempts to scrutinise the S/CP-NRP more actively. Exceeding debt level limits defined by the Maastricht Treaty can trigger stricter EU surveillance over national policies and increase EU level pressure on the government to implement measures for debt reduction. For Eurozone member states there is also a threat of financial fines. It appears that parliaments tend to focus on the binding aspect of the ES and are aware of potential negative EU implications for their government, demanding greater accountability for planned policy actions and measures in case of problematic developments.

Overall, the findings of this contribution suggest that beyond binding rules within the ES, where the EU-related aspect and impact on national policies is the most evident, parliamentary attention to the procedure and prospects for greater accountability might be limited. The largely non-binding EU policy recommendations, which are the main output of the ES, and the rather low national implementation rate (Darvas \& Leandro, 2015) might contribute to the apparent low political salience of the ES in national parliaments more generally. This could suggest that, in practice, a clear link between the ES procedure that, apart from the binding rules, requires other commitments in coordinating multiple national policies at the EU level and national policy-making might be missing. This rather raises concerns from a democratic legitimacy point of view since, even as a soft-governance tool, the ES enables EU steering and guiding of member states' policies (Haas et al., 2020) and "involves the making of political judgements at the European level" (Crum \& Merlo, 2020, p. 407). In this regard, EU targets and objectives in the ES concerning broader socio-economic development in the EU that can influence national policy choices might not be detected and adequately scrutinised and debated by national parliaments, if at all.

The participation of national parliaments in the EU multilevel system is a broadly discussed topic in the literature. The continuous European integration process not only increasingly affected national competencies but also often empowered executive actors and created complex and opaque policy- and decision-making processes, thus raising concerns about the EU democratic deficit (Follesdal \& Hix, 2006). In this regard, the role of the national parliaments together with the European Parliament has been emphasised in securing accountability, essential to democratic governance, in the multilevel EU system (Crum \& Fossum, 2009). Yet integrating national parliaments in the EU multilevel system proved difficult (Raunio, 2009). Although enhanced over time, parliamentary institutional rights (Winzen, 2012, 2021) and practices (Auel et al., 2015b), including especially communication efforts (Auel et al., 2016; Auel \& Höing, 2015; Wonka, 2016) in EU matters still differ across national parliaments. The extent to which national parliaments are able and willing to engage in EU affairs (Auel \& Christiansen, 2015) and play a more active role as an essential part of the democratic structure of the EU multilevel governance varies. Overall, national parliaments face different trade-offs and opportunity costs when considering more active participation in the EU framework and their approaches to EU matters are selective (de Wilde \& Raunio, 2018). The ES connects the EU governance with core national policies, which are also domestically highly politically salient. It has been argued that national parliaments, therefore, should prioritise this procedure because it can be beneficial for enhancing the parliamentary role and democratic functions in both domestic and EU affairs (de Wilde \& Raunio, 2018). Yet the findings of this contribution suggest that, while national parliaments tend to be active at the national stage of the ES in practice, the ES may still fail to generate political motivation for greater parliamentary accountability across member states.

The outlined state of affairs, however, might change in light of the current developments related to the Covid-19 pandemic. The management of the new Recovery and Resilience Facility instrument, providing EU grants and loans to the member states to support their reform and investment efforts, is now linked to the ES (European Commission, 2020). EU financial support will depend on the Commission's assessments of National Recovery Plans and national progress in reform implementation. Therefore, not only the government's programmes, as well as specific stages of the ES, are expected to become increasingly politically salient but 
the ES will also be more directly linked with national policy-making. This could emphasize the political aspect of the ES procedure and strengthen the role and involvement of national parliaments in the EU multilevel system of governance.

\section{Acknowledgments}

I would like to thank Katrin Auel, Guido Tiemann, Susanne Forstner, Sonja Puntscher-Riekmann, participants of the ERC workshop "Raising to a challenge? 10 years of parliamentary accountability of post-crisis EU economic governance," organised by the Hertie School of Governance (10 December 2020), the anonymous referees as well as the editors for their excellent comments and suggestions. Special thanks to my colleagues, native speakers of many different languages as well as all parliamentary officials across chambers investigated in this research for their invaluable assistance in the data collection process. The research leading to these results stems from the PLATO (Post-crisis Legitimacy of the European Union) project, which has received funding from the EU's Framework Programme for Research and Innovation Horizon 2020 under the Marie Skłodowska-Curie Grant Agreement No. 722581. The results reflect only the author's view.

\section{Conflict of Interests}

The author declares no conflict of interests.

\section{Supplementary Material}

Supplementary material for this article is available online in the format provided by the author (unedited).

\section{References}

Alesina, A., Roubini, N., \& Cohen, G. D. (1997). Political cycles and the macroeconomy. MIT Press.

Amtenbrink, F., \& Repasi, R. (2016). Compliance and enforcement in economic policy coordination in EMU. In A. Jakab \& D. Kochenov (Eds.), The enforcement of EU law and values. Ensuring member states' compliance (pp. 145-181). Oxford University Press.

Armingeon, K., Wenger, V., Wiedemeier, F., Isler, C., Knöpfel, L., Weisstanner, D., \& Engler, S. (2019). Comparative political data set 1960-2017 [Data set]. Comparative Political Data Set. https://www.cpdsdata.org/index.php/data

Armstrong, K. (2013). The new governance of EU fiscal discipline. European Law Review, 38(5), 601-617.

Auel, K. (2007). Democratic accountability and national parliaments-Re-defining the impact of parliamentary scrutiny in EU affairs. European Law Journal, 13(4), 487-504.

Auel, K., \& Christiansen, T. (2015). After Lisbon: National parliaments in the European Union. West European
Politics, 38(2), 261-281.

Auel, K., Eisele, O., \& Kinski, L. (2016). From constraining to catalyzing dissensus? The impact of political contestation on parliamentary communication in EU affairs. Comparative European Politics, 14(2), 154-176.

Auel, K., \& Höing, O. (2015). National parliaments and the Eurozone crisis: Taking ownership in difficult times? West European Politics, 38(2), 375-395.

Auel, K., \& Neuhold, C. (2018). Europeanisation of national parliaments in European Union member states: Experiences and best-practices (Study for the European Parliament's Greens/EFA Group). Institute for Advanced Studies. https://irihs.ihs.ac.at/id/ eprint/4746

Auel, K., Rozenberg, O., \& Tacea, A. (2015a). Fighting back? And if yes, how? Measuring parliamentary strength and activity in EU affairs. In C. Hefftler, O. Rozenberg, \& J. Smith (Eds.), The Palgrave handbook of national parliaments and the European Union (pp. 60-93). Palgrave Macmillan.

Auel, K., Rozenberg, O., \& Tacea, A. (2015b). To scrutinise or not to scrutinise? Explaining variation in EU-related activities in national parliaments. West European Politics, 38(2), 282-304.

Crum, B., \& Curtin, D. (2015). The challenge of making European Union executive power accountable. In S. Piattoni (Ed.), The European Union: Democratic principles and institutional architectures in times of crisis (pp. 63-87). Oxford University Press.

Crum, B., \& Fossum, J. E. (2009). The multilevel parliamentary field: A framework for theorizing representative democracy in the EU. European Political Science Review, 1(2), 249-271.

Crum, B., \& Merlo, S. (2020). Democratic legitimacy in the post-crisis EMU. Journal of European Integration, 42(3), 399-413.

Darvas, Z., \& Leandro, A. (2015). The limitations of policy coordination in the Euro area under European Semester (Bruegel policy contribution 2015/19). Bruegel. https://www.bruegel.org/2015/11/thelimitations-of-policy-coordination-in-the-euro-areaunder-the-european-semester

Dawson, M. (2015). The legal and political accountability structure of 'post-crisis' EU economic governance. Journal of Common Market Studies, 53(5), 976-993.

de Wilde, P., \& Raunio, T. (2018). Redirecting national parliaments: Setting priorities for involvement in EU affairs. Comparative European Politics, 16(2), 310-329.

Eihmanis, E. (2018). Cherry-picking external constraints: Latvia and EU economic governance, 2008-2014. Journal of European Public Policy, 25(2), 231-249.

European Commission. (2020). Recovery plan for Europe. https://ec.europa.eu/info/live-work-traveleu/health/coronavirus-response/recovery-planeurope_en

European Court of Auditors. (2020). The European 
Semester-Country Specific Recommendations address important issues but need better implementation (Special Report 16/2020). https://www.eca. europa.eu/en/Pages/Docltem.aspx?did=54357

European Parliament. (n.d.). Parlemeter. https:// www.europarl.europa.eu/at-your-service/en/ be-heard/eurobarometer/parlemeter-of-theeuropean-parliament?year=eng.aac.eurobarometer. filters.allYears\&type=eng.aac.eurobarometer.filters. type.parlemeter

Eurostat. (2021). General government gross debt. https://ec.europa.eu/eurostat/databrowser/view/ SDG_17_40/default/table

Falkner, G. (2016). The EU's problem-solving capacity and legitimacy in a crisis context: A virtuous or vicious circle? West European Politics, 39(5), 953-970.

Follesdal, A., \& Hix, S. (2006). Why there is a democratic deficit in the EU: A response to Majone and Moravcsik. Journal of Common Market Studies, 44(3), 533-562.

Gattermann, K., \& Hefftler, C. (2015). Beyond institutional capacity: Political motivation and parliamentary behaviour in the early warning system. West European Politics, 38(2), 305-334.

Gattermann, K., Hogenauer, A.-L., \& Huff, A. (2016). Research note: Studying a new phase of Europeanisation of national parliaments. European Political Science, 15(1), 89-107.

Haas, J., D’Erman, V., Schulz, D., \& Verdun, A. (2020). Economic and fiscal policy coordination after the crisis: Is the European Semester promoting more or less state intervention? Journal of European Integration, 42(3), 327-344.

Hallerberg, M., Marzinotto, M. B., \& Wolff, G. B. (2012). An assessment of the European Semester. European Parliament. https://www.europarl.europa.eu/ meetdocs/2009_2014/documents/econ/dv/ studybruegel_/studybruegel_en.pdf

Karlas, J. (2011). Parliamentary control of EU affairs in Central and Eastern Europe: Explaining the variation. Journal of European Public Policy, 18(2), 258-273.

Karlsson, C., \& Peterson, T. (2018). The alleged opposition deficit in European Union politics: Myth or reality? Journal of Common Market Studies, 56(4), 888-905.

Kreilinger, V. (2018). Scrutinising the European Semester in national parliaments: What are the drivers of parliamentary involvement? Journal of European Integration, 40(3), 325-340.

Laffan, B. (2014). Testing times: The growing primacy of responsibility in the euro area. West European Politics, 37(2), 270-287.

Laffan, B., \& Schlosser, P. (2016). Public finances in Europe: Fortifying EU economic governance in the shadow of the crisis. Journal of European Integration, 38(3), 237-249.

Leino-Sandberg, P., \& Salminen, J. (2014). Constitutional change through euro-crisis law: Finland. European
University Institute. https://eurocrisislaw.eui.eu/wpcontent/uploads/sites/55/2019/05/Finland.pdf

Leupold, A. (2016). A structural approach to politicisation in the Euro crisis. West European Politics, 39(1), 84-103.

Lord, C. (2017). How can parliaments contribute to the legitimacy of the European Semester? Parliamentary Affairs, 70(4), 673-690.

Maatsch, A. (2017). Effectiveness of the European Semester: Explaining domestic consent and contestation. Parliamentary Affairs, 70(4), 691-709.

Maurer, A., \& Wessels, W. (2001). National parliaments after Amsterdam: From slow adapters to national players? In A. Maurer \& W. Wessels (Eds.), National parliaments on their ways to Europe: Losers or latecomers? (pp. 425-477). Nomos.

OECD. (n.d.). OECD Journal on Budgeting. http://www. oecd.org/gov/budgeting/oecdjournalonbudgeting. htm

Polk, J., Rovny, J., Bakker, R., Edwards, E., Hooghe, L., Jolly, S., Koedam, J., Kostelka, F., Marks, G., Schumacher, G., Steenbergen, M., Vachudova, M., \& Zilovic, M. (2017). Explaining the salience of antielitism and reducing political corruption for political parties in Europe with the 2014 Chapel Hill Expert Survey data. Research \& Politics. Advance online publication. https://doi.org/10.1177/205316801668 6915

Rasmussen, M. B. (2018). Accountability challenges in EU economic governance? Parliamentary scrutiny of the European Semester. Journal of European Integration, 40(3), 341-357.

Raunio, T. (2005). Holding governments accountable in European affairs: Explaining cross-national variation. The Journal of Legislative Studies, 11(3/4), 319-342.

Raunio, T. (2009). National parliaments and European integration: What we know and agenda for future research. The Journal of Legislative Studies, 15(4), 317-334.

Raunio, T. (2011). The gatekeepers of European integration? The functions of national parliaments in the EU political system. Journal of European Integration, 33(3), 303-321.

Rose, R. (2014). Responsible party government in a world of interdependence. West European Politics, 37(2), 253-269.

Rozenberg, O. (2017). The role of the national parliaments after Lisbon: Potentialities and challenges (PE 583.126). European Parliament. https://www. europarl.europa.eu/RegData/etudes/STUD/2017/ 583126/IPOL_STU(2017)583126_EN.pdf

van den Brink, T. (2018). National parliaments and EU economic performance policies. Impact defines involvement? Journal of European Integration, 40(3), 309-324.

Wehner, J. (2006). Assessing the power of the purse: An index of legislative budget institutions. Political Studies, 54(4), 767-785. 
Wehner, J. (2014). Legislatures and public finances. In M. Shane, T. Saalfeld, \& K. Strom (Eds.), The Oxford handbook of legislative studies (pp. 514-525). Oxford University Press.

Winzen, T. (2012). National parliamentary control of European Union affairs: A cross-national and longitudinal comparison. West European Politics, 35(3), 657-672.

Winzen, T. (2021). The European Semester and parliamentary oversight institutions inside and outside of the euro area. Politics and Governance, 9(3), 100-111.

Wonka, A. (2016). The party politics of the euro crisis in the German Bundestag: Frames, positions and salience. West European Politics, 39(1), 125-144.

Wozniakowski, T., Maatsch, A., \& Miklin, E. (2021). Rising to a challenge? Ten years of parliamentary accountability of the European Semester [Thematic issue]. Politics and Governance, 9(3).

Zeitlin, J. (2016). EU experimentalist governance in times of crisis. West European Politics, 39(5), 1073-1094.

\section{About the Author}

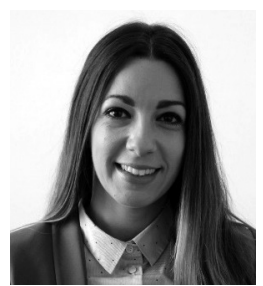

Ivana Skazlic is a PhD Candidate at the University of Vienna, Project Assistant/Pre-Doc Researcher at SCEUS/University of Salzburg, and Fellow at the Institute for Advanced Studies (HIS), Vienna. Her research interests revolve around EU economic governance with a particular reference to the European Semester, national parliaments in the EU and EU legitimacy. 